\title{
SURVEILLANCE OR PUNISHMENT? FROM DOCILE BODIES TO PROGRAMMED BODIES
}

\author{
VIGILÂNCIA OU PUNIÇÃO? DOS CORPOS DÓCEIS AOS \\ CORPOS PROGRAMADOS
}

\author{
Agata Amato Mangiameli ${ }^{1}$ \\ Universidade de Roma
}

\section{Abstract}

The present relationship between punishment and the body is the object of the present investigation. This object, in substance, addresses the very purpose of punishment, becoming one of the main points of current criminal law.

Keywords

Punishment. Body. Criminal law.

\section{Resumo}

As atuais relações entre a punição e o corpo é o objeto da presente investigação. Tal objeto, na substância, aborda a própria finalidade da punição, traduzindo-se em um dos principais pontos do direito penal atual.

\section{Palavras-chaves}

Punição. Corpo. Direito Penal

\section{Incorporeal Punishment}

In the past it was easier to speak about the relationship between punishment and body, and more precisely between punishment and deformed body, when it was customary to quantify the intensity of agony instead of quantifying the duration of detention.

Of course it was easier because physical pain inflicted voluntarily on a convicted individual was immediately related to the body:

\footnotetext{
${ }^{1}$ Professora Catedrática da Faculdade de Direito Universidade de Roma - Tor Vergata
} 
bodies were subjected to whiplashes, to flogging, to exposure, to being raped and precisely to being de-formed. Indeed, whatever their objective, the great rituals of punishment consisting of torture were first and foremost a sort of physical clash between the sovereign and the convicted individual, a hand-to-hand between the revenge of the sovereign and the restrained anger of the people with the person tortured and the executioner being the intermediaries.

And this hand-to-hand showed, prima facie, the asymmetry between the individual who had dared infringe the law and the almighty lord who would impose all of his physical force. It also showed the public nature of all the spheres of life and of the forms of sensitivity, as pointed out by Huizinga:

all aspects of life were public in a pompous and cruel manner. The lepers would sound their rattles and move about lined up as in a procession; beggars would complain in the churches where they displayed their deformities. Each class, each walk of life, each profession was recognized by their attire. The administration of justice, the sale of wares, weddings and funerals, were all announced with processions, cries, wailing and music (HUIZINGA, 1940).

It is more difficult to speak about the relationship between punishment and body, especially punishment and de-formed body, when the human body, is so to speak, abandoned. It is no longer the primary object of the punishment because the contents of the 
penalty (physical punishment, detention, mutilation, capital punishment, etc.) - contents that, according to Hegel are purely circumstantial - must however reflect the proprium of the penal sanction: this is essentially the repression of will, and only indirectly is it a repression of sensitivity. Or better still, the penalty cannot be just any kind of suffering: it must be a distress that purposely denies and humiliates the wicked will embodied in the deeds.

And so, behind this shift of the penalty away from the body of the sentenced individual there is first and foremost the idea that the individual, the I, is not merely identified with his body and not even with the states of his psyche. And this is even more true in the case of penal law: it is the will that is guilty, that is incompatible with the system of freedom. If this is so, the penalty is such when it is addressed to the will, and it respects the dignity of the sentenced person and of his body, even when the penalty affects the body. Torture become intolerable, because it is a disproportionate and unjust measure: it attacks the body, and the more it violates the body, the more far removed it is from its ultimate end. As Foucault says, punishment is

revolting when it is seen from the side of the Lord, where it betrays tyranny, excess, the thirst for revenge, 'the cruel pleasure in punishing'. Shameful when it is seen from the side of the victim (FOUCAULT, 1976)

in that also

the worst of assassins, has at least one thing that needs to be respected when inflicting 
punishment: his/her humanity (FOUCAULT, 1976)

It is therefore necessary to look for techniques and means that punish with an attenuated severity and with a greater sense of proportion; hence the diffusione and generalized use of detention.

The difficulty mentioned earlier: the difficulty about speaking of the relationship between punishment and the body, between punishment and the de-formed body in modern penal law, is in actual fact illusory. It is evident that also detention, considered empirically, is characterized by a physical grab holding of the body of the sentenced individual, who is thus deprived of the freedom of being master of his body, of doing what he pleases. From a certain standpoint, one might say that the difference between the two types of penalty (physical punishiment and detention) consists only in the different amount of objective physical force used, since both end up affecting the physical entity of the convicted individual. And it could not be otherwise. In spite of the best intentions, will and body, even in the offender cannot be isolated from each other, and in any case, the body represents the object that is mediated. In other words will is denied through the body.

If this is so, any penalty will hardly be dissociated from a supplement of physical pain. Even when its main object is the loss of a precise asset and of a specific right, when for instance it is only the pure loss of freedom, there always remains a supplement of punishment that undoubtedly concerns the body. 
Suffice it to think of food rationing, sexual deprivation, being isolated in a cell, the unavoidable promiscuity that being detained involves. Well, even though they do not affect the sensitivity of the convict, as would physical punishment, these and other constraints in any case cause suffering both to the person's will, that is the driver of human acts, and of the body, that is the instrument of the act.

From this standpoint, also detention is a physical punishment: it directly affects the body of the sentenced individual, by putting his rights on hold. And after all, to the detriment of the very development of penal law: from corporal punishment to incorporeal punishment, the boundary between mind and body remains absolutely undetermined, and so each negation of the mind is in and of itself a suffering that is easily reflected on physical reality. The truth is that the body is in any case the field of performing as a subject of law and it is in this sense, and only in this sense, that punishment - what penal law is about - cannot but be also a suffering of the body and not only of the mind.

The foregoing is demonstrated by the abundance of details with which the various penal laws adapt detention to the intellectual, moral and material conditions of each convict, as well as to the severity of the crime, of course. Even though different terms are used, detention is basically articulated always in the same way. For the pathetic individuals who come and go from the overcroweded prisons, there is a so-called soft form of detention: in the past it would be described as a system without chains and with the obligation of speaking in the presence of a guard. For tough convicts, instead, there are special prisons, security sections, harsh prisons, where in the past prisoners would be kept with chains on their feet and with the obligation of silence, being allowed to speak only to the prison guards, or prisoners' hand and feet would be heavily chained 
at all times and they would wear an iron hoop around their body, and were never be allowed to speak to anyone.

Apart from the foregoing, the close relationship between penalty and body of the sentenced person in modern contemporary punishment techniques takes on very special meanings according to the well-known structural-genealogical reconstruction by Michel Foucault. In the era of discipline, power is concentrated and is organized by controlling and regulating the body. The art of the human body appears that is aimed not only at enhancing its abilities, nor is it aimed at making subjection more strongly felt, but at creating a relationship that, through the same mechanism, makes it more obedient the more it is useful and vice versa.

The human body enters into a power mechanism that searches it, breaks it down and reassembles it. Discipline produces bodies that are tamed and trained, 'docile' bodies, it increases the strength of the body (in economic terms of performance) and decreases this same strength (in political terms of obedience). (FOUCAULT, 1976)

So, it is no longer about the absolute power of the sovereign that is communciated through the splendor and public exposure of his punitive spectacles, but an anonymous and ubiquitous power that is not intent on mainly torturing bodies, but it catalogues them and organizes them into institutions that discipline the soul. The prisons first of all, but also mental institutions, residencies, hospitals, schools, boarding schools, etc. 
Institutions that pay attention to the body and to the soul. It is no coincidence that the inventors and promoters of correction houses intended to produce people who were in good health, moderate eaters, ... accustomed to working, eager to run a good business, capable of supporting themselves, and God-fearing. In other terms, the conditions were such as to require discipline, control and security and procedures to train individuals, making them docile and useful, with no room for sex or for chocolate. And this is no coincidence. According to Orwell's apocalyptic fantasy in his famous book 1984, sex and chocolate were allowed only on certain conditions, if not absolutely prohibited where society is governed by Big Brother, where the psychopolice intervenes whenever there is the slightest suspicion that an individual may think, may love, may have fun or may be happy in any way.

At this point it may be useful to ask whether in our globalized (or planet-wide) society it is still important to keep an offender separated and segregated, in other terms is jail still at the top of the list of penalties. Secondly, supposing that detention is still essential, it is worthwhile asking whether it continues to produce subdued and trained bodies, bodies that are docile, or whether it requires from the bodies something else that is more attuned to the current general transformations, that is to say, attuned with the triumph of virtual reality. And finally it is worthwhile asking how the new dimensions, or the progressive artificialization of bodies in the era of cyberspace, interact with the punishment systems. In reality, besides being useful, it is also necessary to ask whether cyborg is, as people normally believe, the new reality, and whether, as Allucquère Rosanne Stone says 
in the virtual era, the default of the individual is expressed in an experienced and imagined physicality. Enunciating it may question not only the disguise of the genre, but also the concreteness of the social individual himself. We must learn to orientate outselves, remembering that cyber means knowing how to direct ourselves, with all our assembled forms and our multiple identities, along the path that unfolds between the two towers of promise and threat, of desire and of technology (STONE, 1997).

Well, does this new reality, the prosthetic body, simply generate alternatives to punishment, or is it capable of proposing alternative forms of punishment? To speak the truth, research and development in the area of prostheses and implants for the human body, that are becoming increasingly refined, suggest global alternatives to penal law itself: we therefore need to see whether these alternatives are legitimate and whether in any case they are compatible with the system of freedom to which we belong.

\section{Model Prisons and New Instruments}

The spasmodic search for alternatives to detention in the literature is not accompanied in practice by a true abandonment of the practice of imprisoning thieves, rapists and killers. On the contrary, prisons have become the laboratories of globalized society where techniques are developed for enclosing in a given space the 


\section{DELICTAE, Vol. 1, No1, Jul.-Dez. 2016 | 148}

waste of globalization and their limits are explored. Renewed arts for segregating bodies are being developed: the casket-cells preserve suigeneris bodies that are bodies merely because they still carry out corporeal functions.

An emblematic example is offered by Pelican Bay Prison in California. This prison is entirely automated and designed in such a way that the inmates cannot come into direct contact neither with the guards nor with the other inmates. In the windowless cells, built out of solid blocks of reinforced concrete and stainless steel, the inmates do not work in the factories of the prison; they have no recreation time, they do not mix with the other inmates. And even the guards are closed in glass booths from which they control the prisoners and communicate with them through a system of loudspeakers. The inmates hardly ever see them and the guards may even never see them. Their task is to make sure that the prisoners are locked up in their cells, that they are not seen at any time and that they themselves cannot see. In other terms, the guards make sure that they are deprived of any form of communication whatsoever.

At first sight, the Pelican Bay project may seem to be an advanced version of a prison, a supertechnological version of the Panopticon (state-of-the-art Security Housing Unit). It therefore looks like the ultimate incarnation of Bentham's dream - total control through absolute surveillance. In actual fact this is not so, and even the first impression one has turns out to be wrong at a closer look. Think of the control function exercised by the Panopticon: its institutions were designed above all as reformatories, houses of correction. Their declared purpose was indeed that of removing the prisoners from the path to perdition that they had embarked upon out of their own volition or down which they had been forced by the circumstances of life. The task was to bring them 
back into the ranks of normal society stopping their moral dissolution, fighting ineptitude and redressing their lack of respect and their non-observance of social rules. As pointed out by Bauman, those were of course

the times of the ethics of labour, when hard and constant work was seen at one and the same time as recipe for a noble life full of merits and the foundation of social order. In practice, therefore, the very idea of correction consisted in putting the inmates to work, giving them a useful, profitable job to do. (BAUMAN, 1999)

In this, as in all the other applications of the project, Bentham showed he was well acquainted with the experiences of his time and with the real problems that the society of repetitive, monotonous and mechanical rhythms has to cope with, virtually cutting construction costs, and another just as important aspect, monitoring workers who had to adjust to the rhythm of factory production, So, whatever their immediate destination, the detention facilities of the Panopticon type were first and foremost factories of disciplined work. Their ultimate goal was to put the prisoners to work, making then do jobs that quite probably were not done voluntarily by free workers, no matter how tempting the remuneration.

Those who were to believe that the Pelican Bay prison is a sort of present day version of the first disciplined work facilities would be wrong. As Foucault states, the latter are 
spaces that ensure fixation and allow for movement; they carve out individual segments and establish operational ties; they mark the places and indicate the values; they ensure obedience by the individuals, but also a better use of time and of gestures. (FOUCAULT, 1976)

In other terms: a mix of real and ideal spaces because characterizations, estimates and hierarchies were projected onto those concrete dwellings. Instead, no productive work is done inside the reinforced concrete walls of Pelican Bay, no training for work, not even a minimum offering of courses to learn a trade. What really counts is that the prisoners must be there, in their solitary cells without air and they must become accustomed to their being excluded. It is not a place of discipline or of organized work, the prison remains the only place, the only territory, in the midst of non-places of post-modernity, where its inhabitants are condemned to being alone in separate spaces, and the sign of separation (and also of exclusion and alienation) in the era of space/time compression is precisely immobility - the figures of Francis Bacon come to mind (here deformation, unlike abstract or dynamic transformation, again has to do with the body, it is static and it is produced in immobility).

Indeed, Pelican Bay does not demand docile and tired bodies, but immobile and depleted bodies, because here the convict has been condemned to give up all his needs, preferences, purposes and meanings. Here the detainee has nothing to do, and he obviously feels depleted out of doing 'nothing': while the tired convict cannot accomplish anything, the depleted convict cannot possibilize. He has put an end to what is possible, and this goes beyond fatigue, a 
perpetual state of finishing. The posture of he who is depleted, as recalled by Gilles Deleuze, is emblematic:

exhaustion will not let itself lie down and, in the heart of the night, it remains seated at its table, an emptied head on prisoner hands. (DELEUZE, 2000)

If the remarks made so far are right, it is truly the era of virtualization, with its Moebius effect, that causes this type of penalty. At a time when all forms of life invent their world and with it a specific space and a specific time, where the usual space-time opens up new spheres of interaction and marks time in an unprecedented manner, where the invention of new speeds and the continuous and problematic acceleration are contemporary to physical mobility, it is clear that a punishment, in order to be a punishment - and cause distress - must cancel what the virtual has to offer.

Just an example. If the virtual blurs the boundaries between established differences, punishing may mean precisely establishing some differences once and for all. The first, essential difference is between guilty and innocent. Now, this is a clear concept, but the thing is that the inmate detained in Pelican Bay, far from sight and beyond anybody's reach, will quite probably remain guilty permanently. In this connection, Bauman's reconstruction is particularly interesting. He rightly points out that life today can be compared to a hierarchy that goes from the global to the local. The first is the freedom of movement, it therefore indicates promotion, advancement and social success; the second, on the contrary has the 
vile smell of defeat, failure, of having been left behind, because immobile. It is no coincidence that ambitions are often expressed in terms of mobility: freedom to choose places, the desire to travel and see the world; instead, when fear is involved, reference is more often made to terms such as: confinement, immobilism, exclusion from places that others can go to, explore and easily enjoy. "High life" is a life of movement; more precisely it consists in the certainty that you can easily move when the first sign of being dissatisfied with staying in a given place arises. Ultimately, freedom has come to mean, first and foremost, freedom of choice, and choosing has conspicuously acquired a spatial dimension. Even the home, in spite of its solidity its being made of bricks and mortar, may generate resentment and rebellion, and not only nostalgia. And it becomes a prison if someone closes us in from the outside, and if getting out of it is a remote or even impossible prospect. Forced immobility, being tied to a place and not being able to go elsewhere, is experiened as an abominable, cruel, repelling condition; and what is offensive, in particular, is the prohibition to move itself, more than frustrating the will to do so. The prohibition to move symbolizes the extreme form of impotence, of loss of power, hence of punishment.

Therefore, that punishment should consist in detention in the era of globalization should not be surprising because it achieves the goal of neutralizing individuals who are potentially dangerous through segregation, and at the same time condemns them to the most painful punishment: immobilization. Indeed, at a time when people are obsessed with the fear of becoming immobile, it is absolutely natural that a harsh and cruel punishment for individuals who have committed crimes should be immobilization. Any other type of punishment compared to this is disgracefully indulgent, 
inadequate and ineffective. It is no coincidence, for instance, that precisely in the era of online communication, at Pelican Bay emails are prohibited, even those that are printed out and delivered via the traditional mail delivery system.

There is one last question. I shall state it briefly: in what way does the progressive artificialization of bodies interact (or can interact) with penal law? In order to answer this question, we need to begin by describing the main feature of prosthetic bodies. Thanks to technology, prosthetic devices range from visible devices, to sound, sensitive and permeable implants that are added to the 'current' body. An example may be of help.

Let us consider an ankle monitor: it makes the body of the sentenced individual visible and auditory. The basic idea (tracking and tailing) is quite simple and has been used for some time now. A battery device inserted into a bracelet that can be worn on the wrist or ankle sends signals to a control room which is constantly manned. If the person wearing the device steps beyond a pre-established perimeter or skips reporting to his/her parole officer, the police or the authorities in charge of the case are immediately alerted. From a first standpoint, one might say that the electronic bracelet (or anklet) can still be associated with the characteristics that are typical of the intervention of penal law: punishment (distress) for the act that was intentionally committed contra legem, against the law. Indeed, it is only an alternative measure to detention and is applied to offenders only in some circumstances and in any case it is bound to be immediately replaced by detention if the individual does not respect the boundaries of the 'prefixed space'. There are no doubts that this new measure is the completion of an ancient project: the electronic 


\section{DELICTAE, Vol. 1, No1, Jul.-Dez. $2016 \mid 154$}

bracelet is no different, if not for the medium, from what used to be done in the past, when misfits/deviants were allowed to rove beyond their assigned neighbourhood provided they wore their distinctive sign.

A closer examination, however, shows that the electronic bracelet redefines the penalty-body relationship. Incorporeal punishment in modern-day society, as said earlier, turns into a computerized punishment, that is all-scrutinizing and from which nothing can be hidden. It challenges the current body. While the latter can be hidden, as it usually is and in various ways by man himself, this new punishment instead takes on the task of tracking his presence at all times. It also challenges the prosthetic body. Unlike any other prosthetic device, the electronic bracelet does not facilitate mobility, it does not expand the scope of action, it does not provide access to different spaces. And, in fact, as supplement to the current body, the bracelet makes the body visible and audible, so that monitoring is continuous, automatic and involuntary, characteristics that normally refer to abstract systems, rather than to human beings.

And so the electronic bracelet becomes just one of the many aspects of the new, sophisticated form of susrveillance. Undoubtedly the panoptic power and the new techniques both put detainees in the position of being observed and controlled at all times so as to avoid that they may evade or go beyond the prefixed spaces. With the former, however, control is only absolute: the detainee knows that he may be monitored at any time, but he knows just as well that his body can be suitably hidden; with the latter, instead, the monitoring is also real besides being absolute: the convict who wears a bracelet knows that at all instants of the day he is under tight 
monitoring because he has a body that uninterruptedly leaves traces of his movements, it is precisely a body on a screen. Paradoxically, therefore, the current body that is a prison for the cybernaut, in a person with a criminal conviction it turns out to be the only bastion around which he can organize a line of defence, the only criterion of resistance against the electronic eye. A convict condemned to wearing an electronic bracelet indeed, is not restricted to a tiny cell; he enjoys a relative freedom of movement, he entertains relationships and yet that visible and audible body, added to his current body, has a special function: punishment (means) in order to control (purpose).

Let us now consider an internal implant: the microchip. It makes the body of the convict audible and sensitive. The basic idea (selectively influencing the centres of pleasure and aggressiveness, as well as memory and reasoning) is not at all new and has been in the testing phase for quite some time now. Also in this case there is a control room and an operator who exercises control. The latter emits commands so that the individual's actions are not the result of a signal issued by his brain that had been registered in the control room as an anomalous emotion. An individual can therefore be observed and controlled, without need for physical contact, through telemetric transmission systems that dispatch information originated by sensors implanted in the human body.

At first sight one might say that placing microchips in the body of a person sentenced under penal law is a measure that is alternative to penal law. In other terms, if the chip regulates will, that is it controls behaviour by crushing the individual's will, such measure has nothing to do with punishment. It may very well be adopted 


\section{DELICTAE, Vol. 1, No1, Jul.-Dez. $2016 \mid 156$}

following a sentence, but its characteristics are those typical of treatment, where will is not only denied but is reified, the individual is no longer an individual but a psychological object and a living machine. Indeed, the adoption of a chip could be justified by the need for therapy which means there needs to be a patient; or justified by the possible rehabilitation of an individual who cannot curb the drives that induce him to have an antisocial behaviour; or justified by the need for neutralization in the presence of irreversible situations.

As is well known, treatment, therapy, rehabilitation, neutralization do not belong to the sphere of penal law. They do not because they presuppose that the individual undergoing treatment has a lack of responsibility that excludes him a priori from the specific field of interest of penal law.

In order for an indicted person to be condemned to a penalty, the only sufficient motivation is that there need to be the conditions envisaged by the law to be able to do so, that is to say that a violation has been committed, that the indicted individual is the person who must respond for that violation, and at the same time the conditions envisaged by the law for guiltiness must be met (guilt and imputability).

There are multiple reasons for an individual to be treated (reeducated, neutralized), and each set of reasons claims they are exhaustive. For instance: an individual who has committed an offence, but is not imputable, may be treated (or has the right to be treated); the same holds for an individual who is not imputable and has not committed any offence, but it is conceivable that he may do so. In any case, the right to treatment is first of all the individual's right not to be punished because he is not imputable. 
If the remarks made so far are correct, the adoption of microchips, as an alternative measure to penal law, does not redefine the punishment-body relationship. And yet the fact that it makes the body audible and sensitive through devices added to the current body, raises considerable problems. The microchip is introduced into the body so that it may capture the world of sensations and emotions that the individual feels, and once they are captured it prevents them from prompting undesired behaviours, so to speak. This may also be acceptable, but the problem is that the chip has a scope of application that is much broader than might be thought initially. Let us imagine that an individual feels a strong emotion when contemplating the painting Liebespaar mit Katze by Kokoschka: an emotion accompanied by the desire to own it. Well, in order to prevent a reprehensible action, the chip comes into action. The painting is safe, but the same cannot be said about the individual. The emotions and desires that are felt are only the emotions and desires that the implant tolerates: the relationship with our body, relationships with others, our attention for things are determined by the implant rather than by our intuitions, emotions and by our knowledge.

And so, just as occurs with psychoactive drugs, an individual who has a microchip implanted in his body is a programme. By using the implant, the clear dividing line between machine and person is lost, because human action is no longer based on the soul and the spirit, it does not require intuition, physical sensations and emotions, and furthermore the capacity of spontaneity cannot vanquish the programming.

And finally, let us imagine a sort of electronic helmet: it would make the body of the inmate sensitive and permeable. The basic idea 


\section{DELICTAE, Vol. 1, No1, Jul.-Dez. $2016 \mid 158$}

(being compelled to play) derives from the remark that whoever plays (videogames, in an MUD, in an $\mathrm{MOO}$, and in general in a virtual community) has in some ways already merged with the computer. This implies that the spaces projected by the game are in some ways considered to be real, because that is where the second I lives: the second $I$ of fluid, emerging, decentred, multiple and constantly changing beings.

In a nutshell, a life lived on the screen and inside the screen, is like a life lived in any real space: you suffer, you love and you heal. The example of a violent encounter between the characters of an MUD clarifies what has just been said. In the game Dungeons \& Dragons the victim is not only the character invented for the game, and the violence is not confined within a free interpretation of the game; the victim is also the author of the character, since the latter is none other than the second $I$ of the author, and the violence abandons the symbolic realm since real life and the life on the screen are not separate and distinct worlds. Indeed, what is it that happens to the real $I$ when his character is destroyed and his body dismembered and scattered all over the MUD? He suffers intensely!

If this is so, cyberspace turns into a space of possibilities also for penal law. In other terms: in the virtual era it is quite possible to propose new penalties produced by the developments in cybernetics that can finally be an alternative to detention and solve the polemics about the endemic conditions of penitentiary institutions. Ultimately, they are the solution for providing an adequate penalty for the culprit, the crime and society. But is it really so?

Let us take the electronic helmet. The sentenced individual condemned to this measure is compelled to play, and since the 
penalty is a punishment that corresponds to the crime committed, he will at least be compelled to play in a manner that reproduces the criminal action. And so, if he has violated a person, (his character) will experience violation; if he has killed, (his character) will be killed ... He will therefore be compelled to come to terms with the ghosts of wakefulness (Wachtsphantasmen), the virtual realities that fall within and not outside of the boundaries of experience.

Albeit only virtually, the distress that the electronic helmet produces cannot be questioned. It is true that it is not the current body that is punished and yet that visible, audible, sensitive and permeable body that is one with the current body, creates an unprecedented form of subjection/objectification. Sensors of all types, virtual interactive environments and digital images inaugurate a pervasive realm inside our body.

\section{Purpose of Punishment}

If these are the possible measures for controlling and directing behaviours, at times as an alternative to penal law, at other times alternatives to detention, it is worthwhile recalling, albeit briefly, the justification of punishment. Without punishment, indeed, any measure required by social customs remains a measure and not a legal punishment. Let us consider here the statement by Mathieu, according to whom the purpose of punishment is to re-establish justice formally and reinstate into the system of freedoms the will that had strayed from it. 
This is the point: the measures suggested thus far (bracelets, chips, electronic helmets) in the electronic brave new world attach priority to ancillary purposes, rather than to the purpopse of punishment. They endorse social defence: in all three cases, the culprit is prevented from harming and the measures are justified by concepts such as deviance, dangerousness, abnormality.

So what, then, is the purpose of legal punishment, in order to avoid therapies of aversion and the temporary slumber of the 'agitators'? The only possible answer is that punishment has the purpose of bringing the culprit back into line with the law, back into the system of freedoms, in accordance with justice. Now, as everyone knows, justice requires the reciprocity of rights and duties, equal treatment, and objectiveness, freedom, on the other hand, requires that action not be betrayed, that it be acknowledged as accountable and hence treated without indulging in any cybernetic determinism of emotions and feelings. Only on the basis of these premises, can we start an investigation into the old and new forms of punishment so that in the end we are not left only with the 'fetishization of complicated machines' with all their deep cybernetic feelings.

\section{References}

BAUMAN. Dentro la globalizzazione. Le conseguenze sulle persona.Bari.1999

FOUCAULT. Sorvegliare e punire. Nascita della prigione. Torino. 1976

GILLES DELEUZE. L'esausto. Napoli. 2000. 
HUIZINGA. Autunno del Medioevo. Firenze. 1940

STONE. Desiderio e tecnologia. Il problema dell'identità nell'era di Internet. Milano.1997 